\title{
Chlorophyll as an indicator of green tea quality
}

\author{
Martina Ošt’ádalová, Bohuslava Tremlová, Jana Pokorná, Martin Král \\ University of Veterinary and Pharmaceutical Sciences Brno, Faculty of Veterinary Hygiene and Ecology, \\ Department of Vegetable Foodstuffs Hygiene and Technology, Brno, Czech Republic
}

Received August 28, 2014

Accepted February 25, 2015

\begin{abstract}
The objective of this work was to study the changes in chlorophyll contents in green teas stored under different conditions and to suggest the most suitable way and length of green tea storage. A secondary aim was to evaluate the possibility of using the chlorophyll content as an indicator of tea freshness. Samples for analysis were obtained from a range of tea-growing regions. Chlorophyll contents were measured using UV-vis spectrophotometry. Chlorophyll absorbance was measured at 642.5 and $660 \mathrm{~nm}$. Prior to storage, chlorophyll concentration in teas ranged from 1.12 to $1.89 \mathrm{mg}$ per $1 \mathrm{~g}$ of tea, which corresponded to data given by other authors. Storage was found to lead to a decline in chlorophyll concentration. From the $6^{\text {th }}$ month of storage onwards, a significant decrease $(P<0.05)$ was observed in all samples, irrespective of storage conditions. Based on the findings of this study, original and metal packaging can be considered the most chlorophyll-friendly. On the other hand, glass and paper packaging stored in direct daylight were found to have the strongest impact on chlorophyll concentration. Overall, it can be concluded that the storage time can have a strong influence on oolong green tea colour as an important qualitative variable. Thus, the shelf-life of tea should be shorter than the 12 months claimed by most manufacturers. Once the relationship between changes in chlorophyll concentration and length of the storage period had been established, the chlorophyll content was suggested as an indicator of the storage time (freshness) of a tea substance.
\end{abstract}

Camellia sinensis L., pigments, tea storage, $U V$-vis spectrophotometry

Tea is one of the world's most common beverages. Recently, green tea has received particular attention due to an increase in its consumption. Green tea production is on the rise worldwide, and the tea arrives in Europe from a variety of tea-growing regions which differ not only in the manufacturing technology, but often also in the tea plant age (Mitscher and Dolby 2006; Sang et al. 2011). Green tea is manufactured from the leaves of a tea plant (Camellia sinensis L.). During the manufacturing process, tea leaves are not subjected to the process of fermentation (or enzymatic oxidation). Thus, green tea is non-fermented. Fresh leaves are subjected to heat treatment immediately after harvest to prevent activation of oxidative enzymes and subsequent fermentation of the contained phenolic substances. As a result, the leaves retain their original green colour as well as the majority of content substances (Othmer 2008; Belitz et al. 2009).

Green teas are a source of important antioxidants and, due to their gentle preparation, most of them are also fairly unstable compared to the fermented ones (Cartaxana et al. 2003; Owuor 2003). In Europe, green tea comes with no unified "guidelines" regarding preparation and storage; rather, these exist in the form of supposedly all-purpose recommendations, with discrepancies between them. So far it has not been established for how long tea can be stored or under what conditions and form. The common knowledge that tea loses its original sensory and pharmacological character has not been scientifically proved. Neither the duration of storage nor its most suitable conditions have been suggested yet, whether concerning tea-selling shops or consumers' homes. It has not been determined, either, how the shelf-life of tea from different tea-growing regions can be estimated. 
An important pigment in green tea is chlorophyll. It is a natural pigment contained in tea leaves and all green parts of plants. Chlorophyll pigments (chlorophylls) are a group of green pigments that can be found in photosynthesizing tissues. They constitute a key element of photosynthesis, one that is needed for light absorption (Hörtensteiner and Kräutler 2011). Originally, the term chlorophyll was only used to refer to the green pigments which enter into photosynthesis in higher plants; later it was extended to include all photosynthetic porphyrin pigments (Velíšek and Hajšlová 2009). In tea leaves and non-fermented teas, chlorophyll is a highly important pigment as its amount determines the final colour of green tea infusion. The fermentation process, on the other hand, transforms chlorophylls into pheophorbides and pheophytins, which give rise to the dark colour of black tea (Harbowy and Balentine 1999). Therefore, pheophorbides and pheophytins are the main products of chlorophyll degradation (Cartaxana et al. 2003).

The objective of this study was to investigate the changes in chlorophyll quantity in green teas stored under different conditions and, based on the results, to suggest the most appropriate storage conditions and time. An additional objective was to assess the possibility of using the amount of chlorophyll in green teas as a freshness indicator.

\section{Materials and Methods}

For the purposes of analysis, samples of green teas not subjected to the process of partial fermentation were purposefully selected to ensure the initial presence of chlorophyll in the leaves. Thus, the variation in chlorophyll stability depending on the duration and conditions of storage could be studied. Fourteen samples of loose teas were analysed; they were harvested in autumn 2012 in different tea-growing regions of China and Taiwan. The samples were obtained from originally-packed products immediately after they were opened. The products from which the samples were taken were obtained in the Czech Republic market (tea-growing region: China, India, Japan) and tea factory from Russian (Sochi) and Vietnamese markets. Table 1 contains an overview of the commercial green tea samples.

The samples were subjected to different storage conditions for the period of 12 months (which is the minimum shelf-life of tea recommended by Czech tea manufacturers). During this period, samples were repeatedly examined for changes in the chlorophyll content. The storage conditions corresponded to those in most consumers' homes. More specifically, the samples were stored in covered containers made of glass (ground flasks), in lidded paper and metal boxes and in original packaging (recloseable, coated paper bags with a plastic film on the outer side). The samples were then stored for the period of 12 months both in cupboards with no direct exposure to either daylight or air and in direct daylight in the laboratory. All samples were stored at a room temperature of $20^{\circ} \mathrm{C}$.

Table 1. Analysed samples of commercial green teas.

\begin{tabular}{llll}
\hline $\begin{array}{l}\text { Sample } \\
\text { number }\end{array}$ & \multicolumn{1}{c}{ Type and name of tea } & Tea-growing region & Province \\
\hline 1 & Gunpowder & China & Zhejiang (lowlands) \\
2 & Yunnan green & China & Assam (lowlands) \\
3 & Darjeeling Green, SFTGFOP1 CH & India & Darjeeling (mountains) \\
4 & Assam Green, Tea OP & India & Assam (lowlands) \\
5 & Sencha Satsuma & Japan & Satsuma (mountains) \\
6 & Gunpowder Temple of Heaven & China & Hubel (mountains) \\
7 & China Sencha & China & En Shi (mountains) \\
8 & En Shi Yu Lu "Green Dew" & China & Hubel (mountains) \\
9 & Green tea & Russia & Sochi (lowlands) \\
10 & Green tea "Class 1" & Russia & Krasnodar (mountains) \\
11 & Green tea "Extra" & Russia & Krasnodar (mountains) \\
12 & Vietnam Tea & Vietnam & lowlands \\
13 & Vietnam Chéngon So & Vietnam (mountains) & mountains \\
14 & Chéuöphoanhai with jasmine - hand made & Vietnam (lowlands) & mountains \\
\hline
\end{tabular}


Chlorophyll determination

The principle of the method was the extraction of chlorophyll in acetone and the subsequent measuring of its absorbance at different wavelengths of 642.5 and $660 \mathrm{~nm}$, using diethyl ether as a blank sample. The amount of chlorophyll in samples was established by calculation. The results are given in $\mathrm{mg}$ per $1 \mathrm{~g}$ of tea (Wright 2005; Ošt’ádalová et al. 2010).

Chlorophyll concentration was calculated using international standard conversion coefficients and linear regression:

$\mathrm{ch}_{\mathrm{c}}=7.12 \times \mathrm{A}_{642.5}+16.8 \times \mathrm{A}_{660}$

$\mathrm{ch}_{\mathrm{c}} \quad$ - total amount of chlorophyll in tea infusion $(\mathrm{mg} / \mathrm{g})$

$\mathrm{A}_{660 \mathrm{~nm}}^{\mathrm{c}}$ - absorbance value at $660 \mathrm{~nm}$

$\mathrm{A}_{642,5 \mathrm{~nm}}^{660 \mathrm{~nm}}$ - absorbance value at $642.5 \mathrm{~nm}$

Tea samples $(1 \mathrm{~g})$ were weighed and bathed in $10 \mathrm{ml}$ diethyl ether. The samples prepared in this way were extracted for 15 minutes and then their absorbance was measured. In all cases, the measurement maximum absorption of the absorption spectrum was checked in a broader wavelength range (Ošt'ádalová et al. 2014).

Statistical analysis

Data were analysed using the R i386 2.15.2 for Windows statistical program. ANOVA test was used to determine the differences in chlorophyll content, Tukey's HSD comparison test was used when the analysis of variances showed significant differences between the groups. Differences were considered significant at $P<0.05$.

\section{Results}

Table 2 shows the concentration of chlorophyll in individual tea samples. The values ranged from 1.18 to $1.98 \mathrm{mg}$ per $1 \mathrm{~g}$ of tea. The highest amount of chlorophyll $-1.98 \mathrm{mg} / \mathrm{g}$ - was found in the Japanese green tea Sencha Satsuma, followed by the Chinese green tea Yunnan $(1.88 \mathrm{mg} / \mathrm{g})$, and the Vietnamese Chéuöphoanhai with jasmine $(1.77 \mathrm{mg} / \mathrm{g})$. The amount of chlorophyll in the above teas was found to be significantly higher $(P<0.05)$ than in the other samples. All of the three samples come from high-mountain tea-growing regions. The lowest amount of chlorophyll was found in the Indian Assam Green Tea OP $(1.18 \mathrm{mg} / \mathrm{g})$, followed by the Russian Green tea "Class 1" $(1.19 \mathrm{mg} / \mathrm{g})$, and the Vietnamese Vietnam Tea $(1.28 \mathrm{mg} / \mathrm{g})$.

Table 2. Mean total amount of chlorophyll (mg/g of tea) in the analysed teas.

\begin{tabular}{llc}
\hline Sample number & Sample type and name & Chlorophyll mean content (mg/g of tea) \\
\hline 1 & Gunpowder & $1.46 \pm 0.13$ \\
2 & Yunnan green & $1.88 \pm 0.02^{\mathrm{a}}$ \\
3 & Darjeeling Green, SFTGFOP1 CH & $1.58 \pm 0.12$ \\
4 & Assam Green, Tea OP & $1.18 \pm 0.16$ \\
5 & Sencha Satsuma & $1.98 \pm 0.11^{\mathrm{a}}$ \\
6 & Gunpowder Temple of Heaven & $1.38 \pm 0.33$ \\
7 & China Sencha & $1.24 \pm 0.99$ \\
8 & En Shi Yu Lu "Green Dew" & $1.34 \pm 0.89$ \\
9 & Green tea & $1.40 \pm 0.33$ \\
10 & Green tea "Class 1" & $1.19 \pm 0.25$ \\
11 & Green tea "Extra" & $1.35 \pm 0.52$ \\
12 & Vietnam Tea & $1.28 \pm 0.08$ \\
13 & Vietnam Chéngon So & $1.50 \pm 0.09$ \\
14 & Chéuöphoanhai with jasmine & $1.77 \pm 0.02^{\mathrm{a}}$ \\
& Mean and Standard Deviation & $1.47 \pm 0.24$ \\
\hline
\end{tabular}

${ }^{a}$ Mean values with common superscript in the same column are significantly different from each other $(P<0.05)$ 
Table 3. Mean total chlorophyll content ( $\mathrm{mg} / \mathrm{g}$ of tea) in green tea samples after a particular way and period of storage (0-6 months and 12 months).

\begin{tabular}{lcccccccc}
\hline Condition & \multicolumn{7}{c}{ Months of storage } \\
\hline & 0 & 1 & 2 & 3 & 4 & 5 & 6 & 12 \\
\hline MP & - & $1.2 \pm 0.1$ & $1.1 \pm 0.2$ & $1.2 \pm 0.2$ & $1.0 \pm 0.1$ & $0.8 \pm 0.1^{\mathrm{a}}$ & $0.5 \pm 0.1^{\mathrm{a}}$ & $0.1 \pm 0.01^{\mathrm{a}}$ \\
OP & - & $1.0 \pm 0.2$ & $1.4 \pm 0.2$ & $1.4 \pm 0.1$ & $1.3 \pm 0.3$ & $1.1 \pm 0.2$ & $0.8 \pm 0.2^{\mathrm{a}}$ & $0.3 \pm 0.04^{\mathrm{a}}$ \\
PDL & - & $1.1 \pm 0.1$ & $0.7 \pm 0.2^{\mathrm{a}}$ & $0.7 \pm 0.2^{\mathrm{a}}$ & $0.6 \pm 0.1^{\mathrm{a}}$ & $0.6 \pm 0.1^{\mathrm{a}}$ & $0.4 \pm 0.1^{\mathrm{a}}$ & $0.06 \pm 0.004^{\mathrm{a}}$ \\
PD & - & $1.2 \pm 0.1$ & $1.1 \pm 0.1$ & $0.8 \pm 0.2$ & $0.8 \pm 0.2$ & $0.6 \pm 0.1^{\mathrm{a}}$ & $0.4 \pm 0.1^{\mathrm{a}}$ & $0.07 \pm 0.005^{\mathrm{a}}$ \\
GDL & - & $1.4 \pm 0.2$ & $0.8 \pm 0.2$ & $0.7 \pm 0.1^{\mathrm{a}}$ & $0.6 \pm 0.1^{\mathrm{a}}$ & $0.5 \pm 0.1^{\mathrm{a}}$ & $0.4 \pm 0.1^{\mathrm{a}}$ & $0.05 \pm 0.001^{\mathrm{a}}$ \\
GD & - & $1.3 \pm 0.3$ & $0.9 \pm 0.1$ & $1.0 \pm 0.1$ & $0.8 \pm 0.1$ & $0.7 \pm 0.1^{\mathrm{a}}$ & $0.6 \pm 0.1^{\mathrm{a}}$ & $0.1 \pm 0.05^{\mathrm{a}}$ \\
Mean & $1.47 \pm 0.24$ & $1.2 \pm 0.13$ & $1.0 \pm 0.23$ & $1.0 \pm 0.26$ & $0.9 \pm 0.24$ & $0.7 \pm 0.20^{\mathrm{a}}$ & $0.5 \pm 0.15^{\mathrm{a}}$ & $0.1 \pm 0.09^{\mathrm{a}}$ \\
\hline
\end{tabular}

Legend: MP - metal packaging, OP - original packaging, PDL - paper packaging stored in direct daylight, $\mathrm{PD}$ - paper packaging stored in a dark place, GDL - glass packaging stored in direct daylight, GD - glass packaging stored in a dark place

${ }^{a}$ Mean values with superscript in the same row are significantly different from initial date of storage $(P<0.05)$

The storage conditions led to changes in chlorophyll concentration, causing it to drop significantly in all samples during the last months of storage, which applied to all conditions of storage. Table 3 shows the mean amount of chlorophyll for each month as well as storage condition.

The initial chlorophyll value was $1.47 \mathrm{mg}$ per $1 \mathrm{~g}$ of tea. Storage (Table 3) led to a steady decrease in chlorophyll concentration. A noticeable and significant decrease $(P<0.05)$ was observed in the $5^{\text {th }}$ month of storage (a decrease of up to $\left.50 \%\right)$. In the $6^{\text {th }}$ month of storage the mean chlorophyll concentration was $0.5 \mathrm{mg}$ per $1 \mathrm{~g}$ of tea and by the $12^{\text {th }}$ month it dropped by $93.20 \%$ (the resulting amount was $0.1 \mathrm{mg}$ per $1 \mathrm{~g}$ of tea). The differences are shown in Fig. 1.

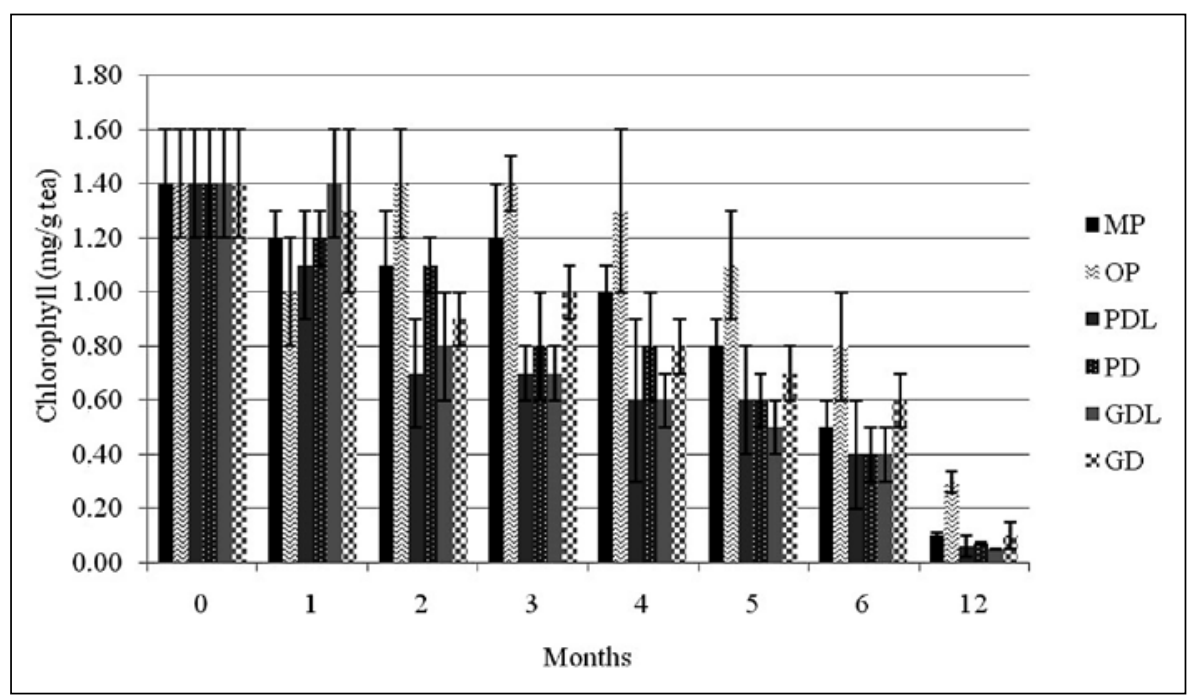

Fig. 1. Changes in the amount of chlorophyll $(\mathrm{mg} / \mathrm{g}$ of tea) in green tea samples after particular conditions and duration of storage (0-6 monhts and 12 months). 
As shown in Fig. 1, the most significant decline in chlorophyll contents was observed in samples stored in direct daylight. Samples stored in direct daylight in paper packaging exhibited a significant $(P<0.05)$ decline in chlorophyll contents (the resulting amount being $0.7 \mathrm{mg}$ per $1 \mathrm{~g}$ of tea) as early as in the $2^{\text {nd }}$ month, and samples stored in direct daylight in glass packaging in the $3^{\text {rd }}$ month (a decrease to $0.7 \mathrm{mg}$ per $1 \mathrm{~g}$ of tea). By the $12^{\text {th }}$ month the chlorophyll contents in these samples were practically eliminated.

The original and metal packaging, on the other hand, were the most chlorophyll-friendly. During the first months, the observed decrease was fairly mild; a significant decrease $(P<0.05)$ was not observed until the $5^{\text {th }}$ month of storage for samples stored in metal packaging (a decline to $0.8 \mathrm{mg}$ per $1 \mathrm{~g}$ of tea) and until the $6^{\text {th }}$ month for samples stored in original packaging (with chlorophyll contents of $0.8 \mathrm{mg}$ per $1 \mathrm{~g}$ of tea). By the $12^{\text {th }} \mathrm{month}$ chlorophyll contents had dropped by $90 \%$ in samples stored in metal packaging (the resulting amount being $0.1 \mathrm{mg}$ per $1 \mathrm{~g}$ of tea) and by $70 \%$ in samples stored in original packaging (the resulting amount being $0.3 \mathrm{mg}$ per $1 \mathrm{~g}$ of tea).

Based on the above-quoted findings, original and metal packaging can be considered the most chlorophyll-friendly. Glass and paper packaging, on the other hand, were found to pose the least favourable conditions $(P<0.05)$.

\section{Discussion}

The findings obtained by the present study correspond to the results of other studies focusing on chlorophyll content in green teas. At the beginning of the experiment, chlorophyll values ranged from 1.18 to $1.98 \mathrm{mg} / \mathrm{g}$. A significant difference $(P<0.05)$ in chlorophyll contents was observed in three samples of teas from high-mountain teagrowing regions (higher values in comparison with other samples). Wei et al. (2011) stated that the chlorophyll content in tea plants varies depending on the environmental and plant-growing conditions, higher contents being connected with lower temperatures and higher relative humidity (which corresponds to mountain regions). The above-quoted findings are in accordance with the findings by Wolf (1959), who studied the total amount of chlorophylls in tea plant leaves and in selected sorts of tea. In his study, chlorophyll contents in green teas were found to reach $1.39 \mathrm{mg}$ per $1 \mathrm{~g}$ of dried leaves. Recently, similar results were published by Wright (2005) and Loranty et al. (2010), who analysed chlorophyll contents in large samples of commercial teas. They found chlorophyll values averaging $1.4 \mathrm{mg}$ per $1 \mathrm{~g}$ of dry substance. Ošt'ádalová et al. (2014) reported the amount of chlorophyll in particular types of teas, coming from the same growing area, but from the 2013 harvest. They found chlorophyll values averaging $1.39 \mathrm{mg}$ per $1 \mathrm{~g}$ of dry substance. It can support the importance of chlorophyll as a stable indicator of the quality of tea. Chlorophyll concentration varies depending on technological processing, too. According to Khamessan and Kermasha (1995) and Daood (2003), during processes such as fermentation the chlorophyll-degradation chlorophyllase enzymes remain active, causing chlorophyll to degrade to pheophorbides and pheophytins. These compounds play a leading role in causing the resulting dark colour of fermented tea. Chlorophyll values in non-fermented fresh teas are not lower than $1 \mathrm{mg}$ per $1 \mathrm{~g}$ of tea (Daood 2003; Owuor 2003; Wei et al. 2011; Milenković et al. 2012).

Storage has been found to lead to the decline in chlorophyll concentration. In some samples, a significant decrease $(P<0.05)$ was observed as early as in the $2^{\text {nd }}$ month of storage; from the $6^{\text {th }}$ month onwards it was observed in all samples. Based on the findings, original and metal packaging can be considered the most chlorophyll-friendly. On the other hand, glass and paper packaging stored in direct daylight were found to pose the least favourable conditions.

Chlorophyll loss can be explained by its sensitivity to light, higher temperatures and $\mathrm{pH}$. According to Astley (2003), storage is accompanied by the release of fatty acids 
and a subsequent acidification of tea substance, which in turn leads to chlorophyll instability. Moreover, access of oxygen to the substance in combination with direct sun rays leads to the release of magnesium from the chlorophyll molecule. Magnesium then starts to be replaced by hydrogen, which leads first to the creation of pheophytins, the hydrogen derivatives, and then pyropheophytins and pheophorbides. The process is accompanied by a change in colour from green to brown as described by Mayer (1987). Pinghai (2006) confirms all of the above, adding that any manipulation with tea samples facilitates the access of oxygen, thus strengthening its effects, which contributes to the degradation of natural pigments, including chlorophyll. The possibility of the effect of enzymes on chlorophyll degradation cannot be excluded. Khamessan and Kermasha (1995) found that processed tea leaves contain a partially active chlorophyllase enzyme which can have a strong impact on the stability of chlorophyll molecules during storage. According to Heaton and Marangoni (1996), it is clear that the degradation of chlorophyll is caused by several enzymes, e.g. peroxidase, lipoxygenase and chlorophyll-oxidase.

It can be concluded that the type and duration of storage can have a significant impact on green tea colour as an important qualitative property. Thus, the shelf-life of tea should be shorter than 12 months as given by most manufacturers.

In addition, it follows from the results of our study that chlorophyll concentration in teas from related tea plants is similar prior to storage and is subject to significant storagerelated changes. As early as in the $2^{\text {nd }}$ month of storage, chlorophyll contents were found to drop below the $1 \mathrm{mg} / \mathrm{g}$ value, which by no means corresponds to chlorophyll values found in fresh, non-fermented teas. For all ways of storing, there was a significant decrease in chlorophyll between the $5^{\text {th }}$ and $6^{\text {th }}$ months of storage. Taking into account the way of storage, it is possible to use chlorophyll content as an indicator of the age (freshness) of tea substance by means of total amount and quantitative loss assessment.

\section{Acknowledgments}

This study was supported by the Internal Grant Agency of the University of Veterinary and Pharmaceutical Sciences Brno (Project No. 75/2010/FVHE).

\section{References}

Astley SB 2003: Antioxidants. Role of antioxidant nutrients in defense systems. In: Caballero B (Eds): Encyclopedia of Food Sciences and Nutrition. Academic Press, Oxford, pp. 282-289

Belitz HD, Grosch W, Schieberle P 2009: Food Chemistry. Springer-Verlag, Berlin, 72 p.

Cartaxana P, Jesus V, Brotas E 2003: Pheophorbide and pheophytin a-like pigments as useful markers for intertidal microphytobenthos grazing by Hydrobiaulvae. Estuar Coast Shelf S 58: 293-297

Daood HG 2003: Chlorophyll. In: Caballero B (Ed.): Encyclopedia of Food Sciences and Nutrition. Academic Press, Oxford, pp. 1196-1205

Harbowy M, Ballentine D 1997: Tea Chemistry. Crit Rev Plant Sci 16: 415-480

Heaton JW, Marangoni AG 1996: Review: Chlorophyll degradation in processed foods and senescent plant tissues. Trends Food Sci Tech 7: 8-15

Hörtensteiner S, Kräutler B 2011: Chlorophyll breakdown in higher plants. Biochim Biophys Acta 1807: $977-988$

Khamessan A, Kermasha S 1995: Biocatalysis of chlorophyllase from Phaeodactylum tricornutum in micellar ternary system containing spans. J Biotechnol 45: 253-264

Loranty A, Rembiałkowska E, Rosa EAS, Bennett RN 2010: Identification, quantification and availability of carotenoids and chlorophylls in fruit, herb and medicinal teas. J Food Compos Anal 23: 432-441

Mitscher L, Dolby V 2006: A book about green tea: Chinese fountain of youth: how to use green tea to prevent cancer and slow down aging (in Czech). ZEMS, Praha, $191 \mathrm{p}$.

Mayer AM 1987: Polyphenol oxidases in plants-recent progress. Phytochem 16: 11-20

Milenković S, Zvezdanović JB, Anđelković TD, Marković DZ 2012: The identificationof chlorophyll and its derivatives in the pigment mixtures HPLC - chromatography, visible and mass spectroscopy studies. Advanced Tech 1: 16-24

Ošt'ádalová M, Pažout V, Straka I 2010: Changes in chlorophyll content during the technological preparation of commercial teas (in Czech). Potravinárstvo 4: 552-557 
Ošt’ádalová M, Tremlová B, Straka I, Pokorná J, Čáslavková P 2014: Evaluation of significant pigments in green teas of different origin. Potravinárstvo 8: 221-227

Owuor P 2003: Chemistry tea. In: Caballero B (Eds): Encyclopaedia of Food Sciences and Nutrition. Academic Press, Oxford, pp. 5743-5752

Othmer K 2008: Food and Feed Technology. John Wiley \& Sons, New Jersey, 1760 p.

Pinghai D 2006: Use of nondestructive spectroscopy to assess chlorophyll and nitrogen in fresh leaves. Dissertation work. Oregon State University, Oregon. $221 \mathrm{p}$.

Sang S, Lambert JD, Ho CT, Yang CS 2011: The chemistry and biotransformation of tea constituents. Pharmacol Research 64: 87-99

Velíšek J, Hajšlová J 2009: Food chemistry 2 (in Czech). Ossis, Tábor, 644 p.

Wei K, Wang L, Zhou J, He W, Zeng J, Jiang Y, Cheng H 2011: Catechin contents in tea (Camellia sinensis) as affected by cultivar and environment and their relation to chlorophyll contents. Food Chem 125: 44-48

Wolf FT 1959: The chlorophyll content of tea. J Torrey Bot Soc 86: 184-189

Wright LP 2005: Biochemical analysis for identification of quality in black tea (Camellia sinensis). Dissertation work. Pretoria, University in Pretoria, 216 p. 